\title{
ОСОБЛИВОСТІ УЛЬТРАСТРУКТУРНО РЕОРГАНІЗАЦІ ЕЛЕМЕНТІВ НЕФРОНА ПРИ ПОЄДНАНІЙ ТРАВМІ ГРУДНО КЛІТКИ І СТЕГНА
}

\author{
(С). М. Гданський
}

\author{
ДВНЗ «Тернопільський державний медичний університет імені І. Я. Горбачевського МОЗ України»
}

\begin{abstract}
РЕЗЮМЕ. В експерименті на білих щурах після нанесення м поєднано травми грудно клітки і стегна із застосуванням електронно мікроскопі було встановлено дистрофічні зміни в подоцитах клубочків і епітеліоцитах канальців, які розвиваються на тлі дисфункціонально перебудови елементів гемомікроциркуляторного русла вже в ранні терміни (на 1-шу добу) після нанесення травми. Дистрофічні зміни в клітинах паренхіми нирок зберігаються і навіть дещо прогресують до 14- доби спостереження, що відбувається на тлі порушено гемомікроциркуляці. І лише з 14доби починають проявлятися регенераторні процеси, які, однак, повністю не завершуються навіть у 28-денний термін. Отримані результати можна вважати морфологічним обґрунтуванням проявів нирково недостатності при поєднаній травмі грудно клітки і стегна, а також збереженням залишкових явищ у віддалений період, що спостерігаються у клінічній практиці.
\end{abstract}

КЛЮЧОВІ СЛОВА: ультраструктура, нефрон, ендотеліоцит, подоцит.

Вступ. Аналіз науково літератури останніх десятиліть як вітчизняно , так і зарубіжно свідчить про значне зростання інтересу до проблеми політравми [1-5]. Проте більшість із наявних наукових праць зорієнтована на вивченні, переважно, Функціональних змін, а також біохімічних процесів, які лежать в основі розвитку ендогенно інтоксикаці і поліорганно недостатності, що розвиваються при таких видах ушкоджень [6, 7]. Щодо робіт морфологічного плану, то вони нечисленні і мають переважно узагальнюючий характер [8].

Відомо, що травматичний шок часто ускладнюється гострою нирковою недостатністю. У 20,2 \% спостережень відмічено порушення азотовидільно функці нирок, у 86,7 \% відзначається проте нурія як результат токсико-дистрофічно нефропаті . У функціонально-відновному періоді продовжують зберігатися залишкові явища у вигляді альбумінурі, лейкоцитурі, мікрогематурі, зниження клубочково фільтраці, сечокам'яно хвороби [9, 10]. Однак, не зважаючи на це, питання про особливості патогенетичних взаємовідносин ушкодження з патологічними змінами у внутрішніх органах при травматичній хворобі продовжує залишатися остаточно не вирішеним.

Мета дослідження: встановити особливості розвитку ультраструктурних змін в елементах нефрона при моделюванні поєднано травми грудно клітки і стегна.

Матеріал і методи дослідження. Експерименти проведено на 18 безпородних білих лабораторних щурах-самцях, які були поділені на 2 групи: контрольну і експериментальну. Експериментальна група включала 5 серій, залежно від термінів спостереження. Тваринам ціє групи під тіопентал-натрієвим наркозом (40 мг $\times \mathrm{K}^{-1}$ маси тіла) за допомогою троакара моделювали лівобічний закритий пневмоторакс з переломом ребра і поєднували х з переломом ліво стегново кістки.
Щурів виводили з експерименту шляхом тотального кровопускання з серця під тіопентал-натрієвим наркозом (60 мг $\times \mathrm{K}^{-1}$ маси тіла тварини внутрішньоочеревинно).

Через 1, 3, 7, 14 і 28 діб посттравматичного періоду забирали шматочки тканини нирок для електронно-мікроскопічного дослідження. Всі експерименти проводилися з дотриманням «Правил проведення робіт з використанням експериментальних тварин».

Результати й обговорення. Нанесення поєднано травми грудно клітки і стегна супроводжувалося вираженими і стійкими ультраструктурними змінами зі сторони нирок і х гемомікроциркуляторного русла. Причому виражені порушення структурно організаці нирково тканини спостерігалися вже навіть у ранні терміни.

Так, протягом перших трьох діб експерименту відмічалося значне повнокров'я гемокапілярів клубочків з проявом у них садж-феномену. При цьому розширені просвіти мікросудин нерідко чергувалися із звуженими за рахунок тиску симетрично розташованих по боках набряклих подоцитів. Цитоплазма як ендотеліоцитів, так і подоцитів виглядала просвітленою, кількість органел у них була зменшеною. Ядра подоцитів збільшувалися у розмірах, х цитоподі виглядали потовщеними i вкороченими, із звуженими проміжками між ними (рис. 1).

У епітеліоцитах проксимальних канальців спочатку відмічалося посилення Функціонально активності, яке проявлялося гіпертрофією мітохондрій з одночасним вкороченням базальних складок плазмолеми. Про посилення функціонального навантаження свідчила конденсація гетерохроматину в ядрах. В подальшому, на 3-тю добу спостереження, приєднувалося виражене збільшення внутрішньоклітинних білкових включень 
Оеляди літератури, ориаінальні дослідження, поеляд на проблему

(рис. 2). При цьому продовжувала наростати кількість мітохондрій з електроннощільним матриксом і чіткими впорядкованими кристами.

Виражені розлади гемомікроциркуляці були типовими і для перитубулярно капілярно сітки (рис. 3, 4). Вони характеризувалися поступовим наростанням повнокров'я мікросудин та формуванням сладжів, що супроводжувалося набряком

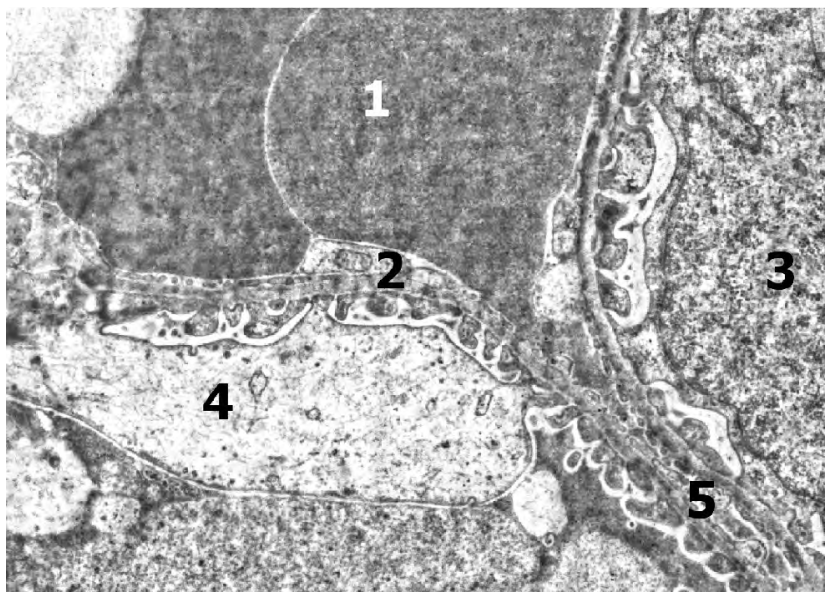

Рис. 1. Електронограма ниркового тільця щура через 1 добу після нанесення поєднано травми грудно клітки і стегна, × 14000.

Еритроцити у розширеному просвіті капіляра - 1, ендотеліоцит - 2, збільшене у розмірах ядро подоцита - 3, просвітлена цитоплазма подоцита - 4, звужений просвіт капіляра між двома симетрично розташованими подоцитами - 5

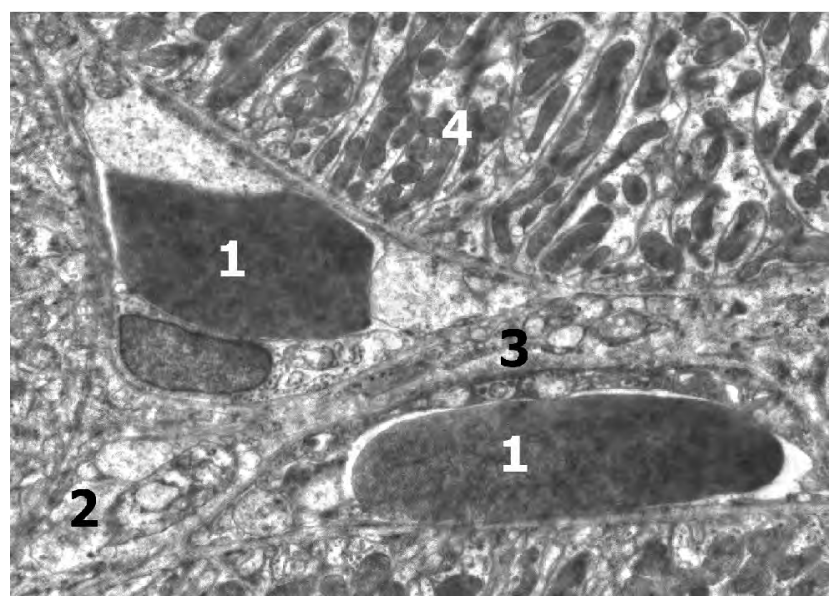

Рис. 3. Електронограма перитубулярно капілярно сітки нирки щура через 1 добу після нанесення поєднано травми грудно клітки і стегна. $\times 14000$.

Формені елементи крові у просвіті капілярів - 1, ендотеліоцит з просвітленою цитоплазмою - 2, деструкція з вакуолізацією органел ендотеліоцита - 3, мітохондрі епітеліоцита - 4.

Період з 7- до 14- доби характеризувався прогресуючим поглибленням деструктивних змін зі сторони структурних елементів складових нефрона. В першу чергу це торкалося фільтраційного бар'єра. На 7-му добу спостереження гемо- ендотеліоцитів з деструктивними змінами х органел і порушенням фенестраці цитоплазми. Базальні мембрани при цьому значно потовщувалися. На 3-тю добу спостерігався розвиток дистрофічних змін також зі сторони епітеліоцитів у вигляді набряку мітохондрій з просвітленням х матриксу i деструкцією крист та формуванням вакуолей на місці зруйнованих органел.

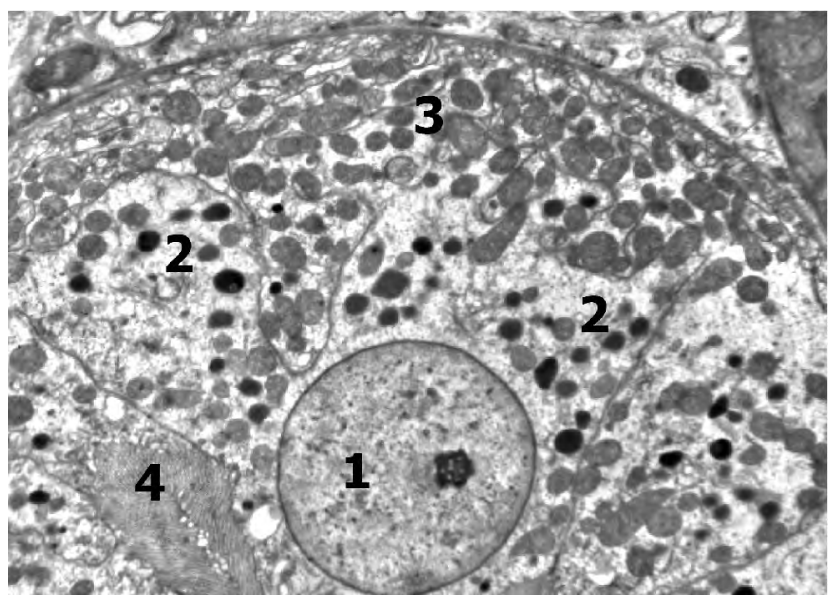

Рис. 2. Електронограма епітеліоцита проксимального канальця нирки щура через 3 доби після нанесення поєднано травми грудно клітки і стегна. $\times 12000$.

Ядро з ядерцем і еухроматином - 1, осміофільні білкові включення - 2, мітохондрі - 3, ворсинки апікально поверхні клітини - 4.

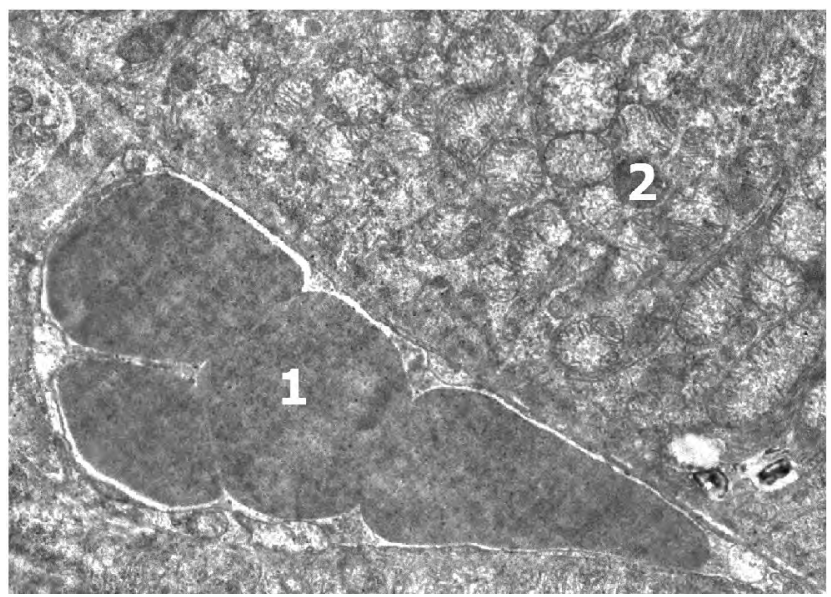

Рис. 4. Електронограма перитубулярно капілярно сітки нирки щура через 3 доби після нанесення поєднано травми грудно клітки і стегна. $\times 14000$.

Сладж еритроцитів у капілярах перитубулярно сітки - 1 , деструкція крист мітохондрій епітелію канальців - 2 .

капіляри продовжували залишатися розширеними і нерідко містили скупчення еритроцитів. Фенестри ендотеліоцитів були збільшені у розмірах. Базальні мембрани виражено потовщувалися. В подоцитах відмічалася деструкція органел і гомо- 
Оеляди літератури, оригінальні дослідження, поеляд на проблему

генізація х матриксу, збільшувалася кількість лізосом.

На 14-ту добу просвіт гемокапілярів продовжував залишатися розширеним, однак нерідко х стінки були хвилеподібно деформованими. Цитоплазма ендотеліоцитів ставала просвітленою і містила порівняно невелику кількость органел біляядерно локалізаці. Глибоких деструктивних змін зазнавали подоцити. х цитоплазма ставала гомогенізованою і іноді містила великі вакуолі із залишками зруйнованих органел. Ядра таких клітин були виражено пікнотичними і деформованими. Цитоподі виглядали значно потовщеними і вкороченими.

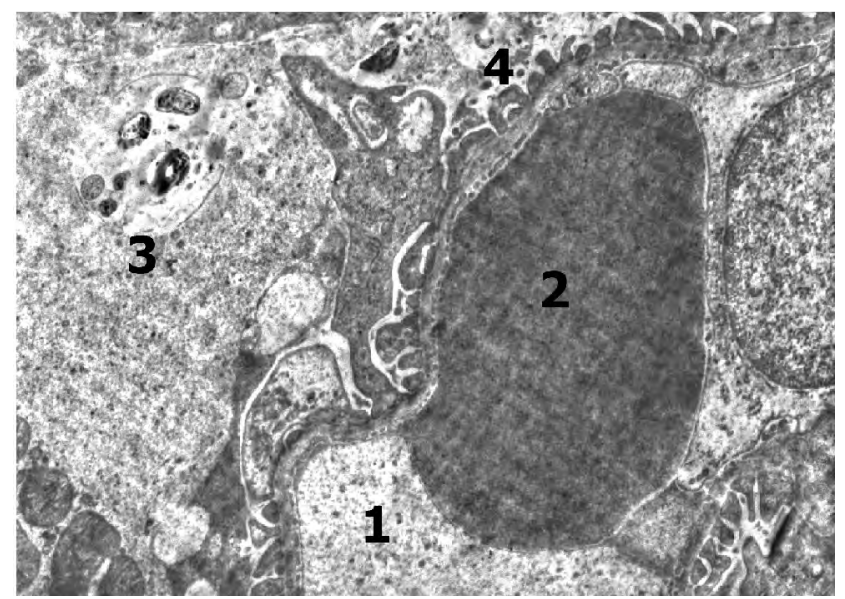

Рис. 5. Електронограма ниркового тільця щура через 14 діб після нанесення поєднано травми грудно клітки і стегна. $\times 16000$.

Просвіт гемокапіляра із деформованою стінкою - 1 , еритроцит - 2, подоцит із гомогенізованою цитоплазмою, великою вакуоллю і деформованим ядром - 3.

Виявлені на ультраструктурному рівні зміни в епітеліоцитах могли бути наслідком, у тому числі, i виражених судинних розладів, морфологічні прояви яких спостерігалися в елементах перитубулярно капілярно сітки. Ендотелій капілярів був виражено набряклим, з просвітленою цитоплазмою, в якій виявлялися залишки зруйнованих органел. Цитоплазма формувала псевдоподі, які випиналися у просвіт мікросудин. Перинуклеарні простори таких клітин були розширеними, ядра дещо набряклими (рис. 7).

Наступний період з 14- по 28-му добу експериментального спостереження характеризувався поступовим розвитком регенераторних процесів з відновленням ультраструктурно організаці елементів паренхіми і гемомікроциркуляторного русла нирок. Це підтверджувалося гіпертрофічною перебудовою клітин, х ядер і збільшенням кількості внутрішньоклітинних органел. Гіпертрофічних змін зазнавали як ендотеліоцити капілярів клубочків, так і подоцити. Збільшені у розмірах ядра подоцитів містили дифузний еухроматин, а х каріолема формувала інвагінати у вигляді внутрішньо-
Проміжки між ними були максимально звуженими (рис. 5).

Прогресування деструктивних змін відбувалося і в епітеліоцитах ниркових канальців. Ядра таких клітин ставали виражено пікнотичними. Конденсовані гранули гетерохроматину займали білякаріолемне положення, сама каріолема була помітно деформована за рахунок утворення неправильно форми інвагінацій. У цитоплазмі спостерігалася масова деструкція органел з руйнуванням крист мітохондрій і формуванням на х місці вакуолей. Звертало на себе увагу збільшення кількості білкових гранул (рис. 6).

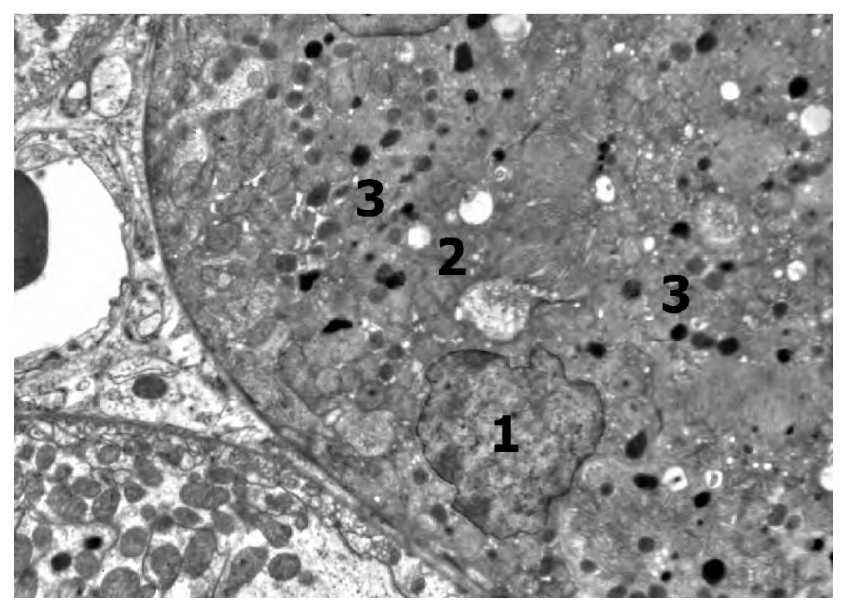

Рис. 6. Електронограма епітеліоцита проксимального канальця нирки щура через 7 діб після нанесення поєднано травми грудно клітки і стегна. × 18000.

Ядро епітеліоцита ниркового канальця - 1, формування вакуолей на місці зруйнованих органел - 2, численні білкові включення підвищено осміофільності - 3.

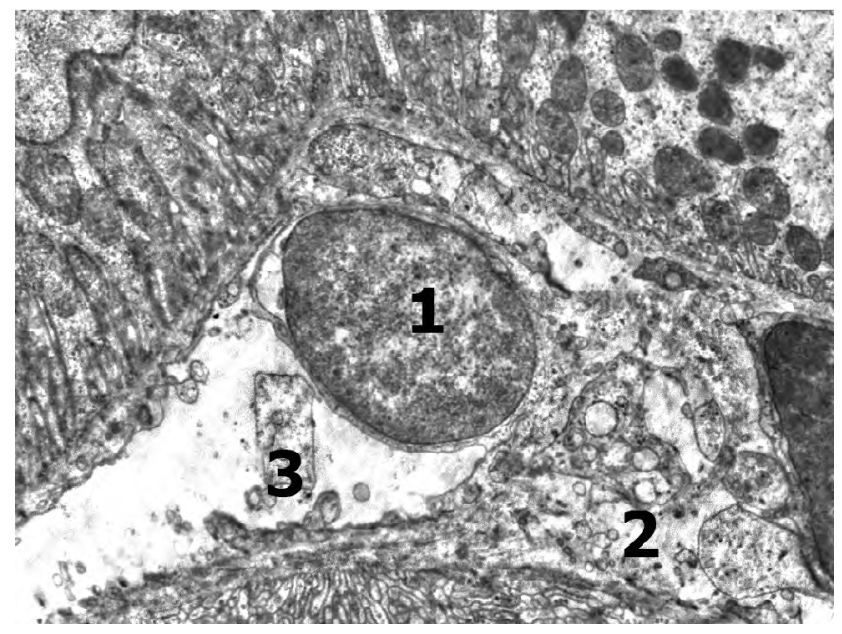

Рис. 7. Електронограма перитубулярно капілярно сітки нирки щура через 7 діб після нанесення поєднано травми грудно клітки і стегна. × 12000.

Ядро ендотеліоцита - 1, цитоплазма ендотеліоцита із зруйнованими органелами - 2, псевдоподі ендотеліоцита у просвіті гемокапіляра - 3 .

ядерних канальців. Цитотрабекули і цитоподі набували звуженого і видовженого вигляду. 
Оеляди літератури, ориаінальні дослідження, поеляд на проблему

В епітеліоцитах ниркових канальців на даний період спостереження також відмічалися продуктивні регенераторні зміни. Відновлювалася структура ядер, які дещо збільшувалися у розмірах, набували округло форми і містили дифузний еухроматин, рівномірно розподілений по всій поверхні зрізу ядра. Збільшувалася кількість різного розміру мітохондрій з електроннощільним матриксом і збереженими кристами, які локалізувалися не тільки на базальній частині клітини між відростками цитолеми, але й визначалися і в центральних та апікальних відділах. Ворсинки апікальних полюсів клітини набували впорядкованого вигляду. Хоча і на даний термін спостереження в цитоплазмі клітин ще можна було спостерігати невеликі осміофільні скупчення білкових включень.

Регенераторні процеси в епітеліоцитах канальців відбувалися на тлі відновлення структурно організаці і функціонально активності ендотелію капілярів перитубулярно сітки. Знижувався набряк цитоплазми ендотеліоцитів, у ній зменшувалася кількість зруйнованих органел, виявлялися новоутворені мітохондрі , відновлювалися розміри і стан фенестр, посилювався мікропіноцитоз. Ядра займали центральну позицію, містили еухроматин і набували округло форми з гладкою поверхнею каріолеми. Більш структурованою ставала базальна мембрана. Просвіт капілярів був співрозмірний з діаметром еритроцитів, які іноді зустрічалися в ньому.

Результати, отримані при ультраструктурному дослідженні нирок щурів після нанесення поєднано травми грудно клітки і стегна, дозволили встановити дистрофічні зміни в подоцитах клубочків і епітеліоцитах канальців, які розвиваються на тлі дисфункціонально перебудови елементів гемомікроциркуляторного русла вже в ранні терміни (на 1-шу добу) після нанесення травми. Дистрофічні зміни в клітинах паренхіми зберігаються і навіть дещо прогресують до 14- доби спостереження, що відбувається на тлі порушено гемомікроциркуляці . І лише з 14- доби починають проявлятися регенераторні процеси, які однак повністю не завершувалися навіть у 28-денний термін. Отримані результати можна вважати морфологічним обґрунтуванням проявів нирково недостатності при поєднаній травмі грудно клітки і стегна.

Висновки. 1. Ультраструктурні зміни дистрофічного характеру в елементах нефрона після нанесення поєднано травми грудно клітки і стегна у щурів виникають в ранні терміни (вже на 1-шу добу) на тлі порушено гемомікроциркуляці і зберігаються до 14 дня спостереження з наступним поступовим відновленням структурно організаці клітин.

2. Збільшення кількості білкових включень в цитоплазмі епітеліоцитів канальців може свідчити про порушення фільтраційно-резорбційно функці нефронів з альбумінурією.

3. Повного відновлення ультраструктурно організаці елементів нефрона не відбувається навіть у віддалені терміни постравматичного періоду (до 28 діб), що може складати підґрунтя залишкових явищ, які спостерігаються у клінічній практиці.

Перспективи подальших досліджень. Подальші дослідження дозволять експериментально обгрунтувати напрямки і обсяг консервативного лікування для запобігання розвитку нирково недостатності у травмованих хворих.

\section{ЛІТЕРАТУРА}

1. Cramp I. M. Analysis of multiple organ system failure in trauma and nontrauma patient / I. M. Cramp, D. A. Duncan, R. Wears // Amer. Surg. - 2000. - Vol. 12. - P. 72-78.

2. Gaiko G. V. Treatment of fractures in victims of complex injuries with ITO multi-functional external frames (MEF-ITO) / G. V. Gaiko, A. V. Kostiuk// The 13th SICOT Traine's Meeting. Abstracts. St. Petersburg, Russia: Morsar AV, 2002. P. 206-207.

3. Ринденко С. В. Надання медично допомоги примножинних та поєднаних ушкодженнях / С. В. Ринденко // Ортопедия, травматология и протезирование. - 2007. № 2. - С. $86-90$.

4. Лікування постраждалих з полісистемними та поліорганними пошкодженнями в сільській місцевості / С. О. Гур'єв, П. В. Танасієнко, М.М. Хімич, В. Д. Шищук. Житомир : СПД Медведева, 2008. - 112 с

5. Політравма як медико-соціальна проблема (ризикорієнтований підхід) / С. О. Гур'єв М. І. Березка, О.С.Соловийов, С. П. Сацик // Медицина сьогодні і завтра. 2012. - № 1. - С. 28-31.
6. Bone R. S. SIRS and CARS / R. S. Bone // Crit. Care Med. - 1996. - Vol. 7. - P. 115-118.

7. Коган А. О. Вплив експериментально політравми на функціональний стан солітарно нирки / А. О. Коган, В. П. Пішак // Мед. перспективи. - 2004. - Т. 9, № 3. C. $4-10$.

8. Чернов А. П. Вопросы клинико-нозологической структуры сочетанных повреждений / А. П. Чернов, С. В. Рынденко, А. Э. Фесков // Проблемы военного здравоохранения. - К. : Янтар, 2002. - С. 105-111.

9. Стороженко А.А. Синдром хронического экологопрофессионального перенапряжения и особенности изменений внутренних органов у раненых и больных в экстремальных условиях организма / А. А. Стороженко // Труды ВМА им. С.М. Кирова. - Ст-Петербург, 1993. Т. 235. - С. 8-27.

10. Смекалкина Л. В. Современные аспекты травматической болезни у участников боевых действий / Л. В. Смекалкина // Хирургия. Журнал им. Н.И. Пирогова. 2010. - № 12. - С. 89-93. 


\title{
FEATURES OF ULTRASTRUCTURAL REORGANIZATION OF NEPHRON ELEMENTS AT COMBINED INJURIES OF THE CHEST AND HIPS
}

CS. M. Hdanskyi

\author{
SHEI «Ternopil State Medical University by I.Ya. Horbachevsky of MPH of Ukraine»
}

SUMMARY. In the experiment on white rats, after application of combined injuries of the chest and hips degenerative changes in glomerular podocytes and tubular epitheliocytes were found using electron microscopy. They developed on the background of the restructuring of dysfunctional elements of hemomicrocirculation bed in the early stages (on the 1st day) after injury. Degenerative changes in renal parenchyma cells persisted and even had some progress to the 14th day of observation. It happened on the background of hemomicrocirculation damage. The regenerative processes appeared only on the 14th day, however, not completely ended even in 28 days. The results can be considered as a justification of morphological manifestations of renal failure at associated trauma of the chest and hips, as well as of the residual effects in the remote period, observed in clinical practice.

KEY WORDS: ultrastructure, nephron, endothelial cells, podocytes.

Отримано 23.03.2015 